\title{
Formulasi Nanopartikel Tanaman Herbal untuk Terapi Kanker
}

\author{
Al Masitoh*, lyan Sopyan \\ Program Studi Sarjana Farmasi, Fakultas Farmasi, Universitas Padjadjaran \\ *email: maratulmahdiyyah@gmail.com \\ (Submit 12/8/2019, Revisi 20/8/2019, Diterima 21/8/2019)
}

\begin{abstract}
Abstrak
Kanker termasuk masaalah kesehatan utama di Dunia dan termasuk penyebab kematian nomor dua setelah kardiovaskular. Obat herbal saat ini banyak digunakan untuk pengobatan kanker karena kelimpahan senyawa kimianya yang berpotensi sebagai anti-kanker. Namun tanaman herbal kebanyakan sediaannya kurang larut air dan memiliki bioavailabilitas yang kurang baik. Sehingga perlu dilakukan modifikasi secara fisik ataupun kimia untuk meningkatkan kelarutannya. Salahsatu modifikasi secara fisik yaitu dari segi Formulasi. Nanopartikel adalah salah satu formulasi yang dapat mengatasi masalah-masalah tersebut karena Nanopartikel mampu memperbaiki kelarutan obat herbal dan dapat masuk dan menargetkan sel kanker secara spesifik.
\end{abstract}

Kata kunci : kanker, nanopartikel, tanaman herbal

\section{Outline}

- Pendahuluan

- Metode

- Hasil

- Pembahasan

- Kesimpulan

- Daftar Pustaka

\section{Pendahuluan}

Kanker termasuk masalah kesehatan utama di seluruh dunia. Di Amerika Serikat, National Cancer Institute memperkirakan 1.665 .540 kasus baru kanker dan 585.720 kematian yang menyertainya pada tahun 2014 (Howlader et al., 2014).

Sedangkan di Indonesia prevalensi kanker mencapai 135.000 kasus pertahun. Menurut data tersebut Indonesia dinobatkan menjadi negara setelah Vietnam dengan kasus kanker terbanyak di wilayah ASEAN pada tahun 2007. Sejalan dengan itu, sejumlah besar senyawa, baik alami maupun sintetis, diskrining atas kemampuannya untuk mengobati kanker (Depkes RI, 2007). 
Sel kanker adalah sel dengan pertumbuhan abnormal dan tidak terkendali yang dapat merusak sel-sel normal disekitarnya. Hal ini terjadi karena sel tersebut gennya bermutasi saat sel mengalami pertumbuhan (Depkes RI, 2009).

National Institute of Health telah memperkirakan lebih dari 80.000 senyawa sejak 1990 (National Cancer Institue, 2006). Skrining telah difokuskan pada senyawa yang ditujukan untuk mengobati kanker tertentu, seperti paru-paru (Daoud et al., 2014), payudara (Koval et al., 2014) dan kanker prostat (Ding et al., 2013), dan mereka telah berfokus pada efek anti-tumor secara umum. Sementara tes-tes ini mengungkapkan efek anti-tumor, dalam kebanyakan kasus mereka tidak mengungkapkan apakah senyawa tersebut mungkin berguna untuk mengobati kanker dari sudut pandang praktis. Banyak dari agen terapi potensial ini memiliki kelarutan dalam air rendah (lebih dari $40 \%$ dari semua zat baru dianggap tidak larut dalam air) (Savjani et al., 2014), memiliki ketersediaan hayati yang rendah, atau kombinasi keduanya. Oleh karena itu, kelarutan senyawa ini harus diubah melalui modifikasi kimia atau melalui formulasi.

Dalam segi formulasi telah dikembangkan metode nanomedicine yang dapat menargetkan obat ke sel tumor secara spesifik (Keen, 2008). Formulasi partikel nano dapat meningkatkan ketersediaan hayati dari obat yang larut dalam air yang buruk dengan mengatasi pembubaran obat dan / atau permeabilitas. Menyetel sifat fisikokimia pembawa nanopartikel dapat mengubah penyerapan, distribusi, dan eliminasi obat selama transit usus (Li dan Huang, 2008). Nanopartikel dan mikropartikel dapat meningkatkan transportasi transelular dan paraseluler dalam saluran GI ( (Gamboa dan Leong, 2013;Mathiowitz et al., 1997). Khususnya, komposisi bahan kimia pembawa, ukuran, dan morfologi telah terbukti menjadi faktor penentu penting dari transportasi nanopartikel melintasi usus setelah pemberian oral (Bhardwaj et al., 2006). Ukuran partikel, khususnya dalam kisaran nanometer, juga dapat meningkatkan disolusi obat untuk obat yang larut dalam air yang buruk (Möschwitzer dan Müller, 2007).

Selain obat sintesis terdapat juga obat dari sumber daya alam seperti tanaman yang berpotensi sebagai anti kanker, tetapi diperlukan terlebih dahulu pengujian senyawa sitotoksik dan menyaring ekstrak tanaman mentah.

Obat herbal penting untuk pengobatan kanker karena kelimpahan senyawa kimianya yang memberikan kesempatan lebih besar dalam untuk menemukan bahan aktif baru senyawa anti kanker (Newman et al., 2007)

Dipercayai bahwa efek antikanker tanaman berkembang dengan menekan enzim perangsang kanker, memperbaiki DNA, merangsang produksi enzim antitumor dalam sel, meningkatkan kekebalan tubuh, dan menginduksi efek antioksidan (Sarkar et al., 2011).

\section{Metode}

Metode yang digunakan yaitu studi pustaka dengan mengumpulkan beberapa jurnal melalui sarana internet dari web terpercaya seperti elsevier. 
Pencarian pustaka dengan menggunakan kata kunci Formulasi Nanopartikel Senyawa Tanaman Herbal Untuk Terapi Kanker dari 22 jurnal yang didapat, dipilih beberapa jurnal yang memiliki tema formulasi nanopartikel tanaman herbal untuk kanker. Kemudian dilakukan analisis dari jurnal-jurnal yang didapa melalui sarana internet.

\section{Hasil}

\section{Tabel 1. Formulasi Nanopartikel Tanaman Herbal Untuk Terapi Kanker}

\begin{tabular}{|c|c|c|c|c|}
\hline Tanaman Herbal & \begin{tabular}{|l} 
Formulasi \\
Nanopartikel
\end{tabular} & Metode dan ukuran & Pengujian & Referensi \\
\hline $\begin{array}{l}\text { Kurkuminoid } \\
\text { Temulawak }\end{array}$ & $\begin{array}{l}\text { Nanopartikel } \\
\text { bersalut lipid } \\
\text { padat }\end{array}$ & $\begin{array}{l}\text { Teknik Penyalutan, ukuran } \\
\text { partikel } 648.4 \pm 95 \mathrm{~nm}\end{array}$ & $\begin{array}{lr}\text { Kanker Pankreas, } & \text { Kanker } \\
\text { Ovarium, } & \text { Kanker } \\
\text { payudara dan } & \text { Kanker } \\
\text { Kolon. } & \end{array}$ & $\begin{array}{l}\text { (Riki et al. } \\
2017) \text {. }\end{array}$ \\
\hline $\begin{array}{l}\text { Zerumbon Rimpang } \\
\text { Lempuyang gajah }\end{array}$ & Kitosan & $\begin{array}{l}\text { Enkapsulasi dengan gelasi } \\
\text { ionik Na-TPP sebagai agen } \\
\text { penaut silang. ukuran } \\
\text { partikel } \\
280-680 \mathrm{~nm}\end{array}$ & Sel Kanker T47D & $\begin{array}{l}\text { (Andasari, } \\
\text { 2017). }\end{array}$ \\
\hline $\begin{array}{l}\text { Ekstrak Daun Parang } \\
\text { Romang }\end{array}$ & $\begin{array}{l}\text { polimer } \\
\text { biodegradabel } \\
\text { kitosan }\end{array}$ & $\begin{array}{l}\text { Gelasi lonik, ukuran partikel } \\
149,0 ; 178,4 ; 262,7 \mathrm{~nm} \text {. }\end{array}$ & Sel Kanker HeLa & $\begin{array}{l}\text { (Ningsi, } \\
\text { 2013). }\end{array}$ \\
\hline $\begin{array}{l}\text { Ekstrak etanol daging } \\
\text { buah Mahkota Dewa }\end{array}$ & Kitosan-TPP & $\begin{array}{l}\text { Gelasi lonik, ukuran partikel } \\
90.9 \text { dan } 162.87 \mathrm{~nm} \text {. }\end{array}$ & $\begin{array}{l}\text { Kanker Serviks dan } \\
\text { Payudara }\end{array}$ & $\begin{array}{l}\text { (Napsah et } \\
\text { al., 2014). }\end{array}$ \\
\hline $\begin{array}{l}\text { Silimarin dari Silybum } \\
\text { marianum } \\
\text { (Asteraceae). }\end{array}$ & $\begin{array}{l}\text { Sistem BSA nano } \\
\text { dengan } \\
\text { desolvasi }\end{array}$ & $\begin{array}{l}\text { Metode Emulsifikasi, ukuran } \\
\text { partikel } 174,23 \pm 13,94 \mathrm{~nm}\end{array}$ & Kanker prostat & $\begin{array}{l}\text { (Ambarwati, } \\
\text { 2017). }\end{array}$ \\
\hline $\begin{array}{l}\text { Vinkristin dari Vinca } \\
\text { rosea }\end{array}$ & AuNP & $\begin{array}{l}\text { Metode Bottom up, ukuran } \\
\text { partikel rata-rata }<100 \mathrm{~nm}\end{array}$ & Sel Kanker CCRF-CEM & $\begin{array}{l}\text { (Pertiwi et al., } \\
\text { 2014). }\end{array}$ \\
\hline $\begin{array}{l}\text { Ekstrak kulit manggis } \\
\text { merah }\end{array}$ & Kitosan-STPP & $\begin{array}{l}\text { Metode Gelasi ionik, ukuran } \\
\text { partikel } 214,4 \pm 3,51 \mathrm{~nm} \text { dan } \\
285,2 \pm 5,99 \mathrm{~nm}\end{array}$ & Kanker kolon & $\begin{array}{l}\text { (Ningsih et } \\
\text { al., 2017). }\end{array}$ \\
\hline $\begin{array}{l}\text { Tanaman } \\
\text { Clerodendrum } \\
\text { (Lamiaceae) } \\
\text { C.phlomidis } \\
\end{array}$ & $\begin{array}{l}\text { Silver } \\
\text { Nanopartikel }\end{array}$ & - & sel line kanker & $\begin{array}{l}\text { (Lakshmi \& } \\
\text { Bai, } 2016 \text { a) }\end{array}$ \\
\hline $\begin{array}{l}\text { Tanaman } \\
\text { Clerodendrum } \\
\text { (Lamiaceae) } \\
\text { C.phlomidis } \\
\end{array}$ & $\begin{array}{l}\text { Silver } \\
\text { Nanopartikel }\end{array}$ & - & MCF-7, EAC, HT29 & $\begin{array}{l}\text { (Lakshmi \& } \\
\text { Bai, } 2016 \text { b) }\end{array}$ \\
\hline $\begin{array}{l}\text { Tanaman } \\
\text { Clerodendrum } \\
\text { (Lamiaceae) } \\
\text { C.phlomidis } \\
\end{array}$ & AgNPs & - & $\begin{array}{l}\text { Tikus Wistar yang } \\
\text { diinduksi dengan DEN }\end{array}$ & $\begin{array}{l}\text { (Sriranjani et } \\
\text { al., 2016) }\end{array}$ \\
\hline $\begin{array}{l}\text { Tanaman } \\
\text { Clerodendrum } \\
\text { (Lamiaceae) } \\
\text { C.serratum } \\
\end{array}$ & AgNPs & - & Sel EAC & $\begin{array}{l}\text { (Nagdeva et } \\
\text { al., 2012) }\end{array}$ \\
\hline $\begin{array}{l}\text { Tanaman } \\
\text { Clerodendrum } \\
\text { (Lamiaceae) } \\
\text { C.serratum } \\
\end{array}$ & AgNPs & - & $\begin{array}{l}\text { mencit Swiss } \\
\text { diinduksi sel DLA }\end{array}$ & $\begin{array}{l}\text { (Raman et al., } \\
\text { 2015). }\end{array}$ \\
\hline $\begin{array}{l}\text { Ekstrak Kunci Pepet } \\
\text { (Kaemferia rotunda) }\end{array}$ & & Kitosan Na-TPP & $\begin{array}{l}\text { Kanker Payudara pada } \\
\text { Tikus }\end{array}$ & $\begin{array}{l}\text { (Khakim } \\
\text { al., 2017). }\end{array}$ \\
\hline $\begin{array}{lr}\text { Curcumin } & \text { Beta } \\
\text { Siklodekstrin } & \text { dari } \\
\text { Curcuma longa linn }\end{array}$ & Kitosan & $\begin{array}{l}\text { Ukuran partikel } 156,8 \pm 38,3 \\
\text { nm }\end{array}$ & Sel kanker & $\begin{array}{l}\text { (Edityaningru } \\
\mathrm{m} \text { et al., } \\
2015) \text {. }\end{array}$ \\
\hline
\end{tabular}




\section{Pembahasan}

Obat herbal telah dipraktekkan sejak ribuan tahun dan merupakan bagian dari budaya masyarakat Indonesia termasuk negara-negara asia lain seperti Cina, India dan bahkan Nepal. Dalam beberapa dekade terakhir penggunaan obat herbal telah meningkat secara signifikan yang terlihat dari meningkatnya pasar global obat-obatan herbal Karena obat-obatan herbal memiliki lebih sedikit efek samping dibandingkan dengan yang sintetis, penggunaannya telah meningkat. Selain itu, pengembangan suplemen diet herbal dan nutraceuticals telah menyebabkan peningkatan pangsa pasar herbal. Namun, penggunaan " Novel Drug Delivery System" untuk formulasi obat herbal terbilang lambat jika dibandingkan dengan kompleksitas konstituen aktif. Meskipun beberapa formulasi untuk obat herbal ada yang telah dikembangkan dan mereka telah menunjukkan kemanjuran yang mirip dengan yang disintesis secara kimia atau obatobatan modern, namun penelitian lebih lanjut masih diperlukan. Di antara sistem pengiriman obat baru, nanopartikel dianggap penting. Nanopartikel dapat digunakan untuk menargetkan obat herbal ke organ individu dengan selektivitas, pemberian obat, efektivitas dan keamanan yang lebih baik dan dengan demikian mengurangi dosis dan meningkatkan kepatuhan pasien.

Nanopartikel diproses melalui interaksi spesifik antara permukaan nanopartikel dan reseptor permukaan sel yang selanjutnya mengaktifkan berbagai jalur pensinyalan. Selain mekanisme endositosis, nanopartikel juga dapat masuk ke dalam sel melalui penetrasi bilayer pasif. Kemampuan nanopartikel untuk melekat dan melewati membran sel bergantung pada karakteristik fisikokimianya berupa ukuran, komposisi dan muatan permukaannya. Nanopartikel yang ukurannya kecil $(<200 \mathrm{~nm})$ mudah melewati membran sel, sedangkan yang berukuran besar dapat melewati membran dengan menginduksi deformasi membran sel (Tsuda et al., 2015). Komposisi dan muatan partikel mempengaruhi pengambilan partikel. Partikel yang hidrofob akan diabsorbsi lebih cepat daripada partikel yang permukaanya bersifat hidrofil. Meningkatkan hidrofobisitas partikel menambah permeabilitas melalui mukus tetapi mengurangi translokasi melalui dan melintasi sel absorbsi. Karena itu, kesetimbangan sifat hidrofillipofil optimum merupakan sifat yang perlu dimiliki matriks penyusun nanopartikel (Bhardwaj \& Kumar, 2006).

Persyaratan sistem nanopartikulat yang ideal adalah yang seharusnya mampu beredar dalam aliran darah dan harus cukup kecil untuk mencapai sel target dan jaringan. Obatobatan herbal dapat ditargetkan ke berbagai organ seperti otak, paru-paru, hati, ginjal, saluran pencernaan, dl. Aktivitas keseluruhan obat-obatan herbal tergantung pada konstituen aktif yang ada di dalamnya karena mereka memberikan aksi sinergis dan dengan demikian meningkatkan nilai terapeutik. Sebagian besar zat aktif herbal memiliki kelarutan yang buruk dalam air karena sifat hidrofobik mereka. Sifat ini menyebabkan penurunan bioavailabilitas dan peningkatan pembersihan sistemik sehingga diperlukan pemberian berulang atau peningkatan dosis, dan dengan demikian membatasi penggunaan klinis herbal obat-obatan. Karena itu, partikel nano dapat dimanfaatkan untuk meningkatkan kelarutan obat herbal dan membantu melokalisasi obat di tempat tertentu sehingga menghasilkan kemanjuran yang lebih baik dan meningkatkan kepatuhan pasien. 
Seperti pada Nanopartikel Kurkuminoid Temulawak oleh Riki et al., 2017, kemampuan nanopartikel ekstrak kurkuminoid dalam menghambat pertumbuhan sel HeLa lebih tinggi dibandingkan dengan ekstrak, sejalan dengan hasil uji Brine Shrimp Lethality Test (BSLT) yang menunjukkan nanopartikel lebih toksik dibandingkan dengan ekstrak. Hal ini disebabkan nanopartikel dapat masuk ke dalam sel membawa ekstrak kurkuminoid dengan mekanisme endositosis.

Nanopartikel mengacu pada sistem koloid dengan ukuran partikel mulai dari 10 hingga $1000 \mathrm{~nm}$. Nanopartikel memiliki beberapa keunggulan termasuk peningkatan kelarutan, bioavailabilitas peningkatan, peningkatan khasiat, pengurangan dosis meningkatkan penyerapan herbal obat-obatan. Liu et al. mengembangkan nanopartikel poly (DL-lactic acid) yang mengandung triptolide. Untuk mengatasi masalah kelarutan yang buruk dan toksisitas triptolide, nanopartikel dikembangkan dengan polimer biokompatibel dan biodegradable, poli (asam laktat-DL). Ukurannya seragam, berbentuk bulat dengan permukaan halus. Sahu et al. merancang polimer metoksi poly biodegradable dan selfassembling baru (ethylene glycol) -palmitate, untuk pengiriman curcumin ke sel kanker. Sistem terdiri dari metoksi poli (etilen glikol) sebagai bagian hidrofilik, asam palmitat sebagai bagian hidrofobik dan curcumin hadir dalam inti misel polimer. Nanocarrier misel yang disiapkan berbentuk bulat.

\section{Kesimpulan}

Terdapat banyak tanaman yang berkhasiat sebagai antikanker namun masih bermasalah dari segi formulasi karena bioavailabilitas dan kelarutan dalam airnya kurang baik. Pembuatan Nanopartikel terbukti bermanfaat dalam mengatasi masalahmasalah tersebut karena nanopartikel herbal dapat mencapai target yang lebih spesifik dalam target organ sehingga bisa menjadi harapan baru dalam mengobati penyakit kanker.

\section{Daftar Pustaka}

Ambarwati , R. \& Rahmawati , A., 2017. Pengembangan Sistem Pembawa Albumin Nanopartikel Untuk Silimarin Dan Kajian Sifat Fisik Serta Profil Pelepasannya Secara In Vitro. Fitofarmaka No. 2, 7(ISSN:2087-9164).

Andasari , S. D., 2017. Formulasi Nanopartikel Zerumbon dari Rimpang Lempuyang Gajah (Zingiber zerumbet L.) : Enkapsulasi dengan Kitosan dan Aktivitas Sitotoksiknya Terhadap Sel Kanker T47D. Jurnal UMS.

Bhardwaj, V., Naga , M. \& Kumar, V. R., 2006. Polymeric nanoparticles for oral drug delivery. In: Gupta, R.B., Kompella, U.B. (Eds.), Nanoparticle Technology for Drug Delivery. Taylor \& Francis Group, New York, US, pp. 231-271.

Daoud, A., Song, J., Xiao, F. \& Shiang , J., 2014. B-9-3, a novel b-carboline derivative exhibits anti-cancer activity via induction of apoptosis and inhibition of cell migration in vitro.. Eur. J. Pharmacol. 5 (724), pp. 219-230. 
Depkes RI, 2007. Keputusan Menteri Kesehatan Republik Indonesia Nomor : 812/Menkes/SK/ VII/2007 Tentang Kebijakan Perawatan Paliatif.. Jakarta: Depkes RI.

Depkes RI, 2009. Pencegahan Kanker Leher Rahim dan Kanker Payudara.. Jakarta: Direktorat Pengendalian Penyakit Tidak Menular Direktorat Jenderal PPP Departemen Kesehatan RI.

Ding, C. et al., 2013. Novel nitrogen-enriched oridonin analogues with thiazole-fused Aring: protecting group-free synthesis, enhanced anticancer profile, and improved aqueous solubility.. J. Med. Chem, 12(56), pp. 5048-5058.

Edityaningrum, C. A. \& Rachmawati , H., 2015. Peningkatan Stabilitas Kurkumin Beta Siklodekstrin Nanopartikel Dalam Bentuk Gel.. Pharmaçiana, 05(01), pp. 53-60.

Gamboa, J. M. \& Leong , K. W., 2013. In vitro and in vivo models for the study of oral delivery of nanoparticles.. Adv. Drug Deliv. Rev., 6(65), pp. 800-810.

Howlader , N. et al., 2016. SEER Cancer Statistics Review, 1975-2011. National Cancer Institute, Bethesda, MD, http://seer.cancer.gov/csr/1975_2011/.

Keen, J., 2008. Commentary: a step towards a new targeted nanotherapy for pancreatic cancer.. Cancer Biol Ther 2008;7(10):1591-2..

Khakim, A. N. \& Atun , S., 2017. . The Preparation Of Kunci Pepet (Kaempferia rotunda) Extract Nanoparticles Loaded Alginate With Various Calsium Ion Concentration Calsium Concentration.. Jurnal Kimia Dasar, 6(1).

Koval, A. V. et al., 2014. Anti-leprosy drug clofazimine inhibits growth of triple-negative breast cancer cells via inhibition of canonical Wnt signaling.. Biochem. Pharmacol., 4(87), pp. 571-578.

Lakshmi , V. \& Bai , G. V. S., 2016. Anticancer Activity of Clerodendrum Phlomidis (L) Leaves and Its Nanoparticles. .. World Journal of Science and Research, 1(1), pp.1225.

Lakshmi, V. \& Bai, G. V. S., 2016. In Vitro Anticancer Activity of Clerodendrum phlomidis Leaves and Its Silver Nanoparticles on Human Breast Cancer Cell Line (MCF-7). .. Asian Journal of Innovative Research, 1(2), pp.1-5.

Li, S. D. \& Huang, L., 2008. Pharmacokinetics and biodistribution of nanoparticles.. Mol. Pharm. 5 (4), 496-504 (PubMed PMID: 18611037)..

Liu, M., Dong , J., Yang , Y. \& Xu, H., 2005. Anti-inflammatory effects of triptolide loaded poly (d.I-lactic acid) nanoparticles on an adjuvant-induced arthritis in rats.. J Ethnopharmacology 2005;97:219-225.. 
Mathiowitz, E. et al., 1997. Biologically erodable microspheres as potential oral drug delivery systems.. Nature 386 (6623), 410-414 (PubMed PMID: 9121559)..

Moschwitzer, J. \& Miller, R. H., 2007. Drug nanocrystals - the universal formulation approach for poorly soluble drugs. In: Thassu, D., Dellers, M., Pathak, Y. (Eds.), Nanoparticulate Drug Delivery Systems.. Informa Healthcare USA Inc, New York, US, pp. 71-88..

Nagdeva, Katiyar, P. K. \& Singh, R., 2012. Anticancer Activity of Leaves of Clerodendron Serratum Spreng. Am.. J. PharmTech Res, 2(4), pp.452-461..

Napsah, R. \& Wahyuningsih, I., 2014. Preparasi Nanopartikel Kitosan-TPP/Ekstrak Etanol Daging Buah Mahkota Dewa (Phaleriamacrocarpa (Scheff) Boerl) Dengan Metode Gelasi Ionik.. Jurnal Farmasi Sains dan Komunitas No. 1. ISSN : 1693-5683., 11(01), pp. 7-12.

National Cancer Institue, 2006. Fact Sheet: Drug Discovery at the National Cancer Institute. National Institute of Health. [Online] Available at: http://www.cancer.gov/cancertopics/factsheet/NCl/drugdiscover y [Accessed 15 juny 2019].

Newman , D. J. \& Cragg, G. M., 2007. Natural products as sources of new drugs over the last 25 years.. J Nat Prod. 2007;70:461-477..

Ningsi , S., 2013. Formulasi dan Karakterisasi Nanokapsul dari Ekstrak Daun Parang Romang (Boehmeria virgata (Forst) Guill) Berdasarkan Variasi Konsentrasi Inti dan Penyalut.. JF FIK UINAM Vol.1 No. 1.

Ningsih , N., Yasni , S. \& Yulianti , S., 2017. Nanoparticle of Red Mangosteen Peel Extract Synthesis and the Functional Characteristics of Its Encapsulated Products.. J. Teknol. dan Industri Pangan. Vol. 28(1): 27-35 Th. 2017 ISSN: 1979-7788.

Pertiwi , R., Djajadisastra, J., Mutalie , A. \& Pujiyanto , A., 2018. Pembuatan, Karakterisasi dan Uji In Vitro Nanopartikel Emas Berbasis Konjugat Gom ArabVinkristin.. Jurnal IImu Kefarmasian Indonesia, 16(ISSN 1693-1831), pp. 6-11.

Raman , R. P., 2015. Biogenic Silver Nanoparticles Synthesis Using The Extract of The Medicinal Plant Clerodendron serratum and Its In-Vitro Antiproliferative Activity.. Materials Letters. Available at: http://dx.doi.org/10.1016/j. Acces on : 15/06/2019.

Riki, Ambarsari, L. \& Nurcholis , W., 2017. Potensi Nanopartikel Ekstrak Kurkuminoid Temulawak Terhadap Sel Line Kanker Serviks.. Indonesia Natural Research Pharmaceutical Journal, 2(01).

Sarkar , F. H., Li, Y., Wang , Z. \& Padhye , S., 2010. Lesson learned from nature for the development of novel anti-cancer agents: implication of isoflavone, curcumin, and their synthetic analogs.. Curr Pharm Des., pp. 1801-1812. 
Savjani , K. T., Gajjar , A. K. \& Savjani, J. K., 2012. Drug solubility: importance and enhancement techniques. ). ISRN Pharm. 2012, 195727 (PubMed PMID: 22830056.

Tsuda, A. \& Peter, G., 2015. Nanoparticles in the lung environmental exposure and drug delivery. CRC Press. Amerika Serikat. E-book. https://onlybooks.org/nanoparticlesin-the-lung-environmental-exposure-and-drug-delivery-18241. [Online]

Available at:

https://onlybooks.org/nanoparticles-in-the-lung-environmental-exposure

and-drugdelivery-18241. [Accessed 15 Juny 2019]. 